\title{
Definování zranitelných oblastí z hlediska nedostatku vody na území České republiky
}

ADAM BERAN, MARTIN HANEL

Klíčová slova: hydrologická bilance - klimatická změna - model Bilan - sucho

\section{SOUHRN}

V rámci projektu řešeného ve VúV TGM, v.V.i., Strategie ochrany před negativními dopady povodní a erozními jevy prírodě blízkými opatřeními v České republice byly definovány zranitelné oblasti ČR z hlediska nedostatku vodních zdrojů. Stupeň zranitelnosti byl definován pro povodí 3. rádu jak pro pozorované období 1981-2010, tak pro výhledové časové horizonty 2021-2050 a 2071-2100 pro tři různé scénáře klimatické změny. Hydrologické modely povodí byly sestaveny za použití bilančního modelu BILAN. V článku je popsána metodika prací a vybrané dílčí výsledky.

\section{ÚVOD}

Článek seznamuje s dílčími výsledky projektu Strategie ochrany před negativními dopady povodní a erozními jevy prírodě blízkými opatřeními v České republice, který je ve VúV TGM, v.v.i., řešen v posledních letech. Řešení probíhá ve spolupráci s firmami Sweco Hydroprojekt, a.s., Vodohospodářský rozvoj a výstavba, a.s., WASTECH, a.S., a SINDLAR Group, s.r.o.

$\checkmark$ rámci projektu byla modelována hydrologická bilance pro povodí 3. rádu pro pozorované klimatické podmínky i scénáře klimatické změny. Dále bylo řešení zaměřeno na identifikaci zranitelných oblastí České republiky z hlediska nedostatku vodních zdrojů.

Nedostatek vodních zdrojů může být způsoben bud' prírodními poměry, nebo nadměrným užíváním. V budoucím časovém horizontu Ize spíše očekávat změny prírodních poměrů než zásadní změny ve velikosti užívání, nicméně pro některá odvětví může klimatická změna znamenat podstatné zvýšení nároků na vodní zdroje (např. závlahy, chladicí voda). Z tohoto důvodu byla v projektu vyhodnocována klimatická změna na základě indexů zahrnujících také užívání vod, případné změny v budoucím užívání jsou zanedbány.

Pro sucho je charakteristický jeho pozvolný začátek, značný plošný rozsah a dlouhé trvání (Tallaksen aj., 1997). Neudržitelný způsob hospodaření s vodou (včetně její nadměrné spotřeby a znečištění) a předpokládané dopady klimatické změny mohou vést k rozsáhlým dopadům na prírodní prostředí a na společnost. V článku jsou identifikovány oblasti ČR, které jsou a které s nejvyšš pravděpodobností budou k problémům s nedostatkem vody náchylné z hlediska předpokládaných klimatických změn.

\section{DATA A METODY}

\section{Hydrologická bilance}

Pro odhad hydrologické bilance pomocí modelu Bilan je nezbytné mít k dispozici (vstupní) časové řady srážek a teploty vzduchu a pro kalibraci modelu i pozorovaný odtok. $V$ prípadě, že odtok pro území, pro které chceme odhadovat složky hydrologické bilance, není znám (jako v prípadě povodí 3. řádu), je možné postupovat v zásadě dvěma způsoby:

- odvození odtoku pro zájmové území pomocí odčitání a sčítání odtoků z dílčích povodí, popř. s využitím hydrologické analogie (tj. přepočet odtoku pomocí velikosti plochy) nebo

- modelování hydrologické bilance pro dílčí povodía následné průměrování jednotlivých složek na základě velikosti překryvu dílčího povodí s povodím 3. rádu.

První způsob umožnuje kalibraci hydrologického modelu přímo pro povodí 3. řádu. Nicméně odtoky odvozené odečítáním průtoků z dílčích povodí jsou značně ovlivněny chybami měření, v jejichž důsledku často dochází k výskytu záporných hodnot, a takto odvozené řady často neumožňují spolehlivou kalibraci hydrologického modelu. $V$ obou prípadech je nezbytné mít $k$ dispozici odtoky z povodí, která jsou relevantní pro posuzované povodí 3. rádu. Zpravidla jde o povodí, která alespoň částečně překrývají povodí 3. řádu.

Pro účely této práce jsme zvolili druhý způsob, tj. pro každé povodí 3 . řádu jsou vyhledána pozorovaná povodí, která mají s posuzovaným povodím společnou plochu. Pro tato povodí jsou odvozeny časové řady srážek a teploty a je nakalibrován hydrologický model Bilan. Jednotlivé složky hydrologické bilance pro povodí 3. rádu jsou pak spočteny jako vážený průměr dotčených dílčích povodí, prričemž váhy jsou úměrné ploše překryvu dílčího povodí s povodím 3. rádu.

Pro kalibraci hydrologického modelu byly využity měsíční časové řady srážek a teploty pro období 1961-2010. Tyto řady byly odvozeny z datasetu gridovaných srážek a teploty v rozlišení $25 \times 25 \mathrm{~km}$. Pro jednotlivá povodí byla interpolací Thiessenovými polygony spočítána prưměrná srážka na povodí, která byla následně korigována na základě vrstvy průměrných srážek (stejné období, rozlišení $1 \times 1$ km, pro toto rozlišení byly $k$ dispozici pouze dlouhodobé průměry) tak, aby průměr srážek pro povodí byl stejný. Podobně byla korigována i teplota - průměrná teplota na povodí z gridované vrstvy byla opravena na základě rozdílu v nadmořské výšce odvozené z gridované vrstvy a z digitálního modelu terénu, přičemž byl uvažován gradient teploty $0,65^{\circ} \mathrm{C} / 100 \mathrm{~m}$.

Pro každé z povodí 3. rádu (na území ČR celkem 120 povodí) byla vybrána pozorovaná povodí aspoň částečně překrývající hodnocené povodí 3. řádu. Pro povodí 3. řádu, pro která nebyla žádná měření k dipozici (zejména malá povodí 
na hranicích republiky - celkem 19 povodí), byly analogony prířazeny ručně. Pro dílčí povodí pak byla modelována hydrologická bilance pomocí modelu Bilan. Pro výpočet výsledné bilance (vážený průměr dílčích povodí) byla velikost překryvu dílčího povodís povodím 3. rádu vztažena jednak k velikosti povodí 3. rádu, jednak k velikosti dílčího povodí. Ideálně bychom chtěli, aby celé povodí bylo pokryto dílčím povodím a zároveň aby dílčí povodí nebylo významně větší než povodí 3. rádu. Postup je podrobněji rozepsán ve zprávě Hanel aj., 2015b.

Pro výpočet hydrologické bilance byl použit model Bilan s měsíčním krokem výpočtu. Model má osm volných parametrů, výpočtem se modeluje potenciální evapotranspirace, územní výpar, infiltrace do zóny aerace, průsak touto zónou, zásoba vody ve sněhu, zásoba vody v půdě a zásoba podzemní vody. Odtok je modelován jako součet tří složek - prímého, hypotermického a základního odtoku (Horáček, 2009; Máca aj., 2013; Vizina a Horáček, 2015).

\section{Scénáře klimatické změny}

Modelování dopadů klimatické změny na hydrologickou bilanci bylo provedeno pro povodí 3. rádu celé ČR, za tímto účelem byla odvozena řada scénářů změny klimatu. Tyto scénáŕe byly založeny na 15 simulacích regionálních klimatických modelů (RCM), které jsou výstupem projektu ENSEMBLES. Součástí tohoto souboru modelů jsou i referenční scénáre změny klimatu, které byly identifikovány v rámci projektu TA02020320 Podpora dlouhodobého plánování a návrhu adaptačních opatření v oblasti vodního hospodářství v kontextu změn klimatu. Tyto scénáře jsou dále označovány jako rSCEN1 (pesimistický), rSCEN2 (neutrální) a rSCEN3 (optimistický). Právě tyto scénáre byly použity pro odhad zranitelnosti povodí z hlediska nedostatku vody. Tvorba scénár̆ů klimatické změny je podrobně popsána ve zprávě Hanel aj. (2015a), použití simulací regionálních klimatických modelů pro hydrologické modelování je popsáno v Hanel aj. (2010).

\section{Indexy zranitelnosti povodí}

Pro porovnání jednotlivých povodí z hlediska zranitelnosti vůči nedostatku vodních zdrojů byly pro každé povodí 3 . rádu stanoveny niže uvedené indexy, vycházející z měsíčních řad. Vstupními daty pro jejich výpočet jsou pozorované řady o uživání vod spolu s řadami potenciální evapotranspirace, srážek, minimálního zůstatkového průtoku a $90 \%$ kvantilu průtoku spolu s budoucími řadami podle scénářủ klimatické změny rSCEN1, rSCEN2 a rSCEN3 (Hanel aj., 2015a). Každý index byl spočítán pro pozorované období 1981-2010, dále pak pro výhledové období 2021-2050 a 2071-2100, pro každý scénář zvlášt.

\section{VÝSLEDKY}

Na základě posouzení probíhajících změn a odhadu změn pro dvě budoucí období podle referenčních scénáruu klimatické změny a na základě souboru simulací regionálních klimatických modelů Ize konstatovat následující. Pozorované změny obecně spíše nejsou statisticky významné, výjimkou je růst teploty (kromě podzimu), zvyšování jarní a roční evapotranspirace, zvyšování celkového odtoku v zimním období v jižních Čechách a pokles zásoby vody v půdě v jarním období. Pro časový horizont 2021-2050 často nejsou projektované změny statisticky významné, přinejmenším z hlediska vyhodnocení celého souboru klimatických modelů.

$\checkmark$ prípadě jednotlivých simulací se statisticky významné změny projevují relativně často. Pro vzdálenější časový horizont 2071-2100 jsou změny v celém souboru modelů často statisticky významné, především v jednotlivých ročních obdobích. Naopak změny roční bilance jsou často nejisté. Mezi robustní změny lze zařadit zejména: růst teploty ve všech ročních obdobích, zvyšování zimních a snižování letních srážek, růst jarní a zimní evapotranspirace, pokles zásoby vody $\vee$ půdě $v$ letním období, v roční bilanci a částečně i v jarním období. Z hlediska roční bilance jsou změny srážek, celkového a základního odtoku značně nejisté. Na obr. 1 jsou vidět změny ve srážkách v souboru klimatických modelů pro časový horizont 2071-2100. Na obr. 2 jsou uvedeny změny celkového odtoku pro časový horizont 2071-2100.

Výsledky modelování změn jednotlivých členů hydrologické bilance, vyjádřené indexy určujícími míru zranitelnosti povodí, byly doplněny o průměrnou hodnotu z indexů PP, WPP_ a WQ90_ (sečteno a vyděleno třemi). Všech šest výsledných indexů bylo kategorizováno do čtyř skupin na oblasti bezproblémové, mírně, středně a velmi zranitelné z hlediska dostupnosti vodních zdrojü. Výsledky pro pozorované období ukazují jako velmi zranitelné oblasti ČR jižní Moravu a západní část středočeského kraje. V těchto oblastech jsou nízké průměrné srážky a vysoká potenciální evapotranspirace. Výsledky z projekcí pro roky 2021-2050 a 2071-2100 tyto oblasti rozšiřují pro pesimistický scénáŕ (rSCEN1) a zanechávají pro optimistický scénář klimatické změny (rSCEN3). Je tedy zrejmé, že volba scénáře je stěžejní, nicméně Ize říci, že ke zlepšení neinklinuje ani nejoptimističtější scénár. Na obr. 3 až 5 Ize vidět mapy indexů zranitelnosti povodí pro pozorované období 1981-2010, scénáŕ rSCEN1 (2071-2100) a scénáŕ rSCEN3 (2071-2100). Podrobné výsledky jsou uvedeny ve zprávě Hanel aj., 2015b.

\section{POSUZOVANÉ INDEXY BYLY NÁSLEDUJÍCí:}

$$
\begin{array}{ll}
P P=\frac{P E T}{P} & W Q 90_{-}=\frac{P O V+P O D-V Y P+M Z P}{Q 90} \\
W Q 90=\frac{P O V+P O D+M Z P}{Q 90} & W P P_{-}=\frac{P O V+P O D-V Y P+M Z P}{P-P E T}
\end{array}
$$$$
W P P=\frac{P O V+P O D+M Z P}{P-P E T}
$$

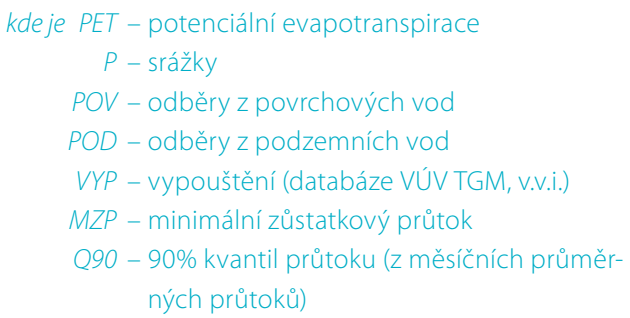




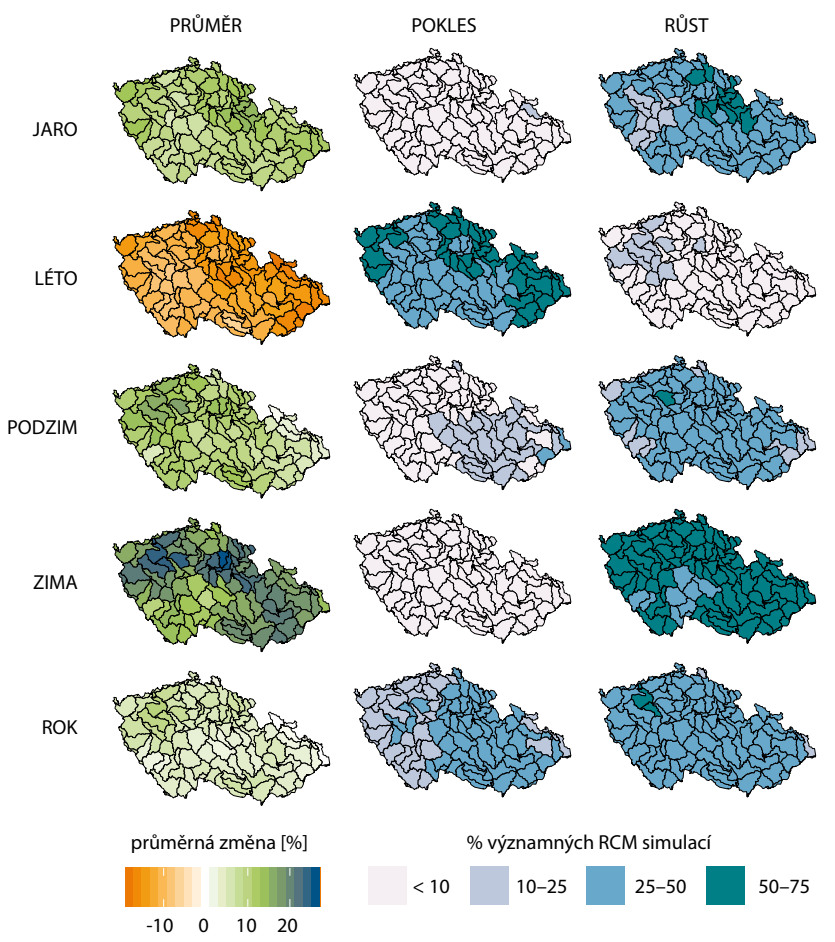

Obr. 1. Simulované změny srážek v souboru klimatických modelů (vlevo), graf vpravo ukazuje procento simulací se statisticky významnými změnami (na hladině významnosti 0,1) k časovému horizontu 2071-2100

Fig. 1. Simulated seasonal and annual mean changes in precipitation in the climate model ensemble (left), the percentage of statistically significant simulated changes (at the 0.1 significance level) for the time horizon 2071-2100
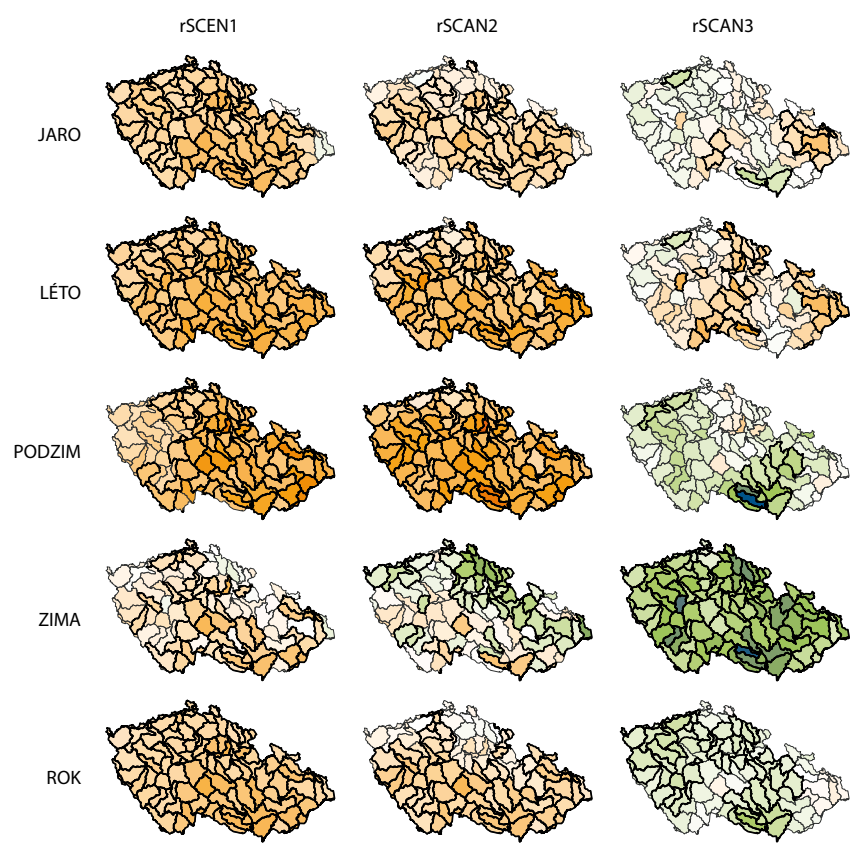

$$
\begin{array}{rrrr} 
& \\
0,5 & 1,0 & 1,5 & 2,0
\end{array}
$$

Obr. 2. Simulované změny celkového odtoku na povodích 3. rádu pro časový horizont 2071-2100 (RM - modelovaný odtok)

Fig. 2. Simulated changes in total runoff for the time horizon 2071-2100
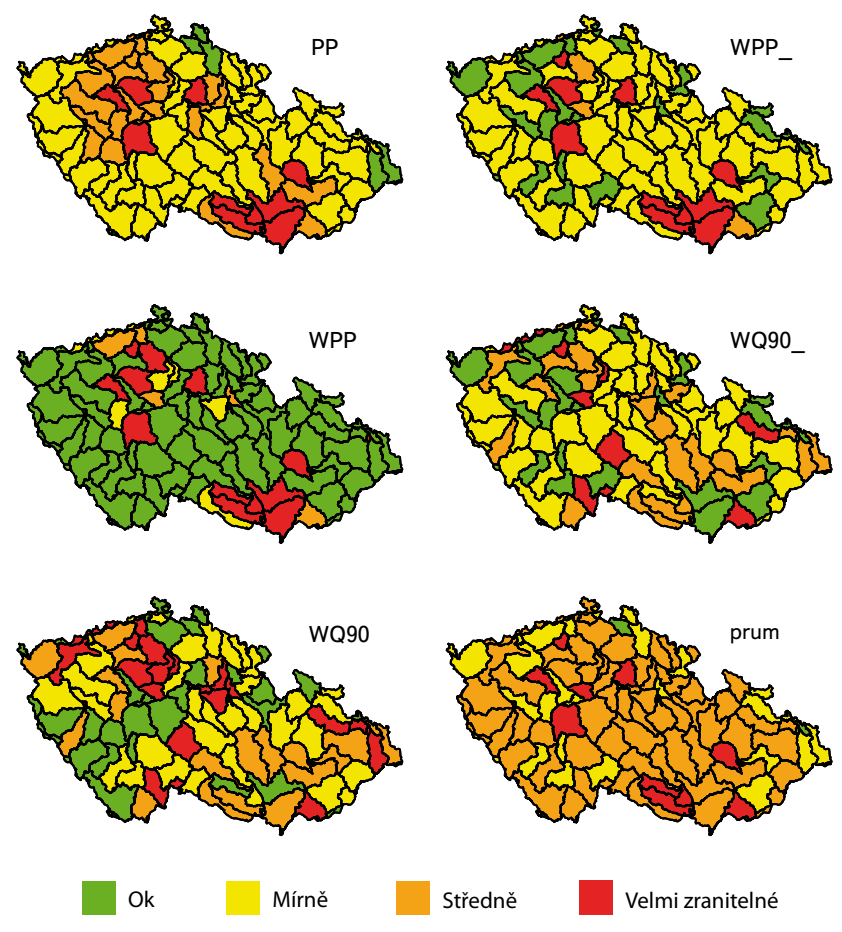

Obr. 3. Posouzení zranitelnosti povodí 3. rádu z hlediska nedostatku vody pomocí vybraných indexů pro pozorované období (1981-2010)

Fig. 3. Observed period (1981-2010)
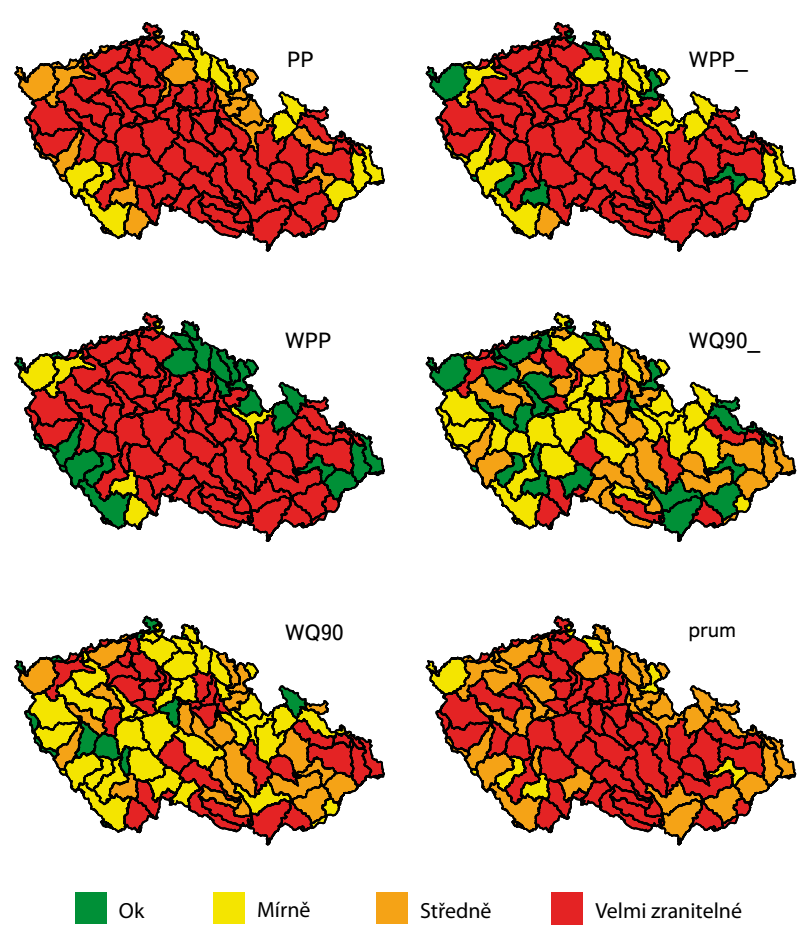

Obr. 4. Posouzení zranitelnosti povodí 3. rádu z hlediska nedostatku vody pomocí vybraných indexů pro výhledové období (2071-2100) pro scénáŕ rSCEN1 Fig. 4. Scenario period (2071-2100) for the rSCEN1 scenario 

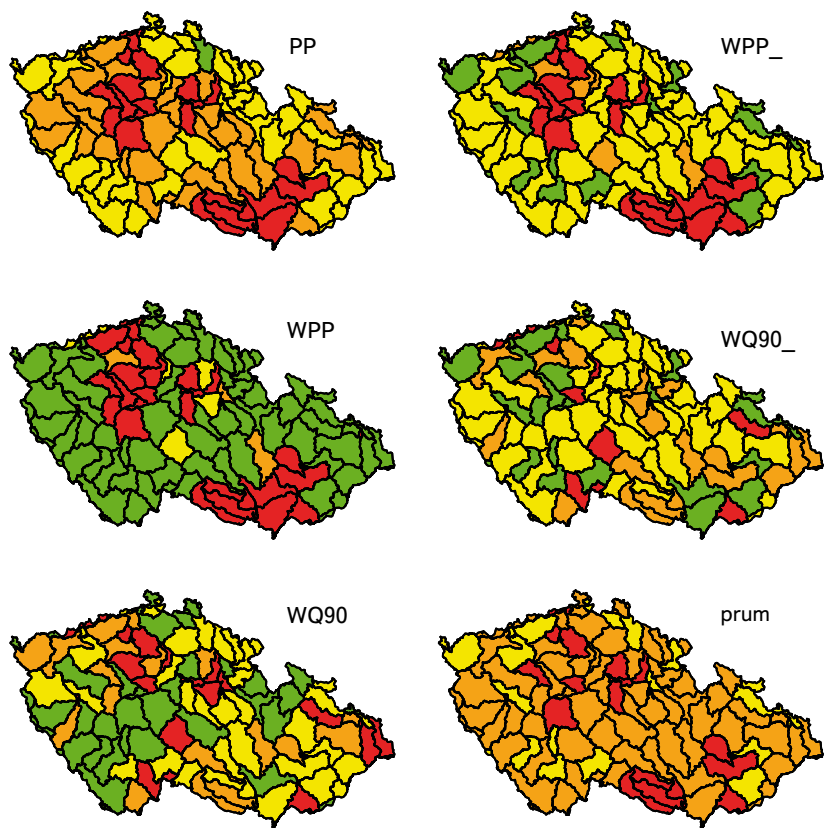

Ok

Mírně

Středně

Velmi zranitelné

Obr. 5. Posouzení zranitelnosti povodí 3. rádu z hlediska nedostatku vody pomoci vybraných indexů pro výhledové období (2071-2100) pro scénář rSCEN3 Fig. 5. Scenario period (2071-2100) for the rSCEN3 scenario

\section{ZÁVĚR}

Na základě scénářu klimatické změny byly modelovány předpokládané změny základních členů hydrologické bilance, a to pro časové horizonty 2021-2050 a 2071-2100. Výsledky potvrzují dosavadní prognózy, a sice zvyšování teploty vzduchu a změny v rozložení srážek $v$ jednotlivých ročních obdobích. Tyto změny vycházejí statisticky významné zejména pro vzdálenější časový horizont 2071-2100. Zároveň byly definovány indexy definující zranitelnost oblasti povodí z hlediska možného nedostatku vodních zdrojů. V pozorovaném období 1981-2010 byly určeny jako zranitelné oblasti jižní Morava a západní části středočeského kraje. Modelované výsledky pro budoucí časové horizonty, je možno ríci, toto varování zprísnily a plošně rozšíríly. Bylo potvrzeno, že ani v prípadě následování optimistického scénáře vývoje klimatu nebude docházet k výraznému zlepšení situace, co se týká ohroženosti vưči nedostatku vodních zdrojů.

\section{Poděkování}

Článek vznikl na základě výzkumu prováděného v rámci projektu Strategie ochrany před negativními dopady povodni a erozními jevy prírodě blízkými opatřeními $\checkmark$ České republice, který je spolufinancován Evropskou unií - Evropským fondem pro regionální rozvoj, Státním fondem životního prostředi ČR a Ministerstvem životního prostředi ČR v rámci Operačního programu Životní prostředí. Scénáře změny klimatu byly vytvořeny v rámci projektu TA02020320, který byl spolufinancován Technologickou agenturou $\check{C} R$.

\section{Literatura}

Hanel, M. a Vizina, A. (2010) Hydrologické modelování dopadů změn klimatu v denním kroku: korekce systematických chyb a prírůstková metoda. Vodohospodářské technicko-ekonomické informace, 52, mimoř. č. II, s. 17-21, ISSN 0322-8916, príloha Vodního hospodárství č. 11/2010

Hanel, M., Beran, A. a Kašpárek, L. (2015a) Scénáře změny klimatu. Technická zpráva. Praha: Výzkumný ústav vodohospodářský T. G. Masaryka, v.v.i.

Hanel, M., Beran, A. a Kašpárek, L. (2015b) Hydrologická bilance povodí 3. řádu. Technická zpráva. Praha: Výzkumný ústav vodohospodářský T. G. Masaryka, v.v.i.

Horáček, S., Rakovec, O., Kašpárek, L. a Vizina, A. (2009) Vývoj modelu hydrologické bilance - BILAN. Vodohospodářskétechnicko-ekonomické informace, 51, mimoř. č. I, s. 2-5, ISSN 0322-8916, přiloha Vodního hospodáršrvíč. 11/2009.

Máca, P., Vizina, A. a Horáček, S. (2013) Optimalizace parametrů modelu BILAN metodou SCDE. Vodohospodářské technicko-ekonomické informace, 55, č. 4, ISSN 0322-8916.

Tallaksen, L.M., Madsen, H., and Clausen, B. (1997) On the definition and modelling of streamflow drought duration and deficit volume. Hydrological Sciences Journal, 42, 1, p. 15-33, DOI:10.1080/02626669709492003.

Vizina, A. a Horáček, S. (2015) Článek Bilan. Vodohospodářské technicko-ekonomické informace, 2015, 57, c.. 4-5, ISSN 0322-8916.

\section{Autoři}

Ing. Adam Beran ${ }^{1,2}$

凶adam_beran@vuv.cz

doc. Ing. Martin Hanel, Ph.D. ${ }^{1,2}$

$凶$ martin_hanel@vuv.cz

${ }^{1}$ Výzkumný ústav vodohospodářský T. G. Masaryka, v.v.i.

2 Česká zemědělská univerzita v Praze, Fakulta životního prostředí

Příspěvek prošel lektorským řízením.

\section{IDENTIFICATION OF REGIONS \\ VULNERABLE TO DEFICITS IN WATER RESOURCES IN THE CZECH REPUBLIC}

\section{BERAN, Adam ${ }^{1,2}$; HANEL, Martin ${ }^{1,2}$}

${ }^{1}$ T. G. Masaryk Water Research Institute, p.r.i.

${ }^{2}$ Czech University of Life Sciences in Prague

Key words: hydrological balance - climate change

- BILAN model - droughts

The results presented in this paper originate from the research conducted by the Hydrology department of the T. G. Masaryk Water Research Institute, p.r.i., within a project "Landscape strategy protection against negative impacts of floods and erosion processes using actions in consistent with nature in the Czech Republic". Vulnerable regions of the Czech Republic in terms of lack of water resources were identified. The degree of vulnerability was defined for $3^{\text {rd }}$ order watersheds for the observed (1981-2010) and scenario (2021-2050 and 2071-2100) periods using three different climate change scenarios. The article presents the applied methodology and description of the most important results achieved in the project. 